\title{
Streptococcus rupicaprae sp. nov., isolated from a Pyrenean chamois (Rupicapra pyrenaica)
}

\author{
Correspondence \\ J. F. Fernández-Garayzábal \\ garayzab@vet.ucm.es
}

\author{
A. I. Vela, ${ }^{1,2}$ G. Mentaberre, ${ }^{3}$ I. Marco, ${ }^{3}$ R. Velarde, ${ }^{3}$ S. Lavín, ${ }^{3}$ \\ L. Domínguez ${ }^{1}$ and J. F. Fernández-Garayzábal ${ }^{1,2}$
}

\author{
${ }^{1}$ Centro de Vigilancia Sanitaria Veterinaria (VISAVET), Universidad Complutense, 28040 Madrid, \\ Spain \\ ${ }^{2}$ Departamento de Sanidad Animal, Facultad de Veterinaria, Universidad Complutense, 28040 \\ Madrid, Spain \\ ${ }^{3}$ Servei d'Ecopatologia de Fauna Salvatge (SEFAS), Departament de Medicina i Cirurgia Animals, \\ Facultat de Veterinària, Universitat Autònoma de Barcelona, 08193 Bellaterra, Spain
}

Streptococci can be isolated as part of the normal flora of the alimentary, respiratory and genito-urinary tracts, as well as the skin of man and different domestic animals (Kilian, 1998), and some species are well-established pathogens causing a variety of diseases such as endometritis, respiratory infections, endocarditis, meningitis, arthritis or mastitis (Chanter, 1997). Members of the genus Streptococcus may also cause diseases in wild animals. Thus, Streptococcus pneumoniae has been associated with a lethal pneumonia in a captive juvenile chimpanzee (Szentiks et al., 2009), Streptococcus didelphis has been isolated from opossums (Didelphis virginiana) with suppurative dermatitis and liver fibrosis (Rurangirwa et al., 2000) and Streptococcus equi subsp. ruminatorum has been documented as an agent of a severe infection in spotted hyenas (Höner et al., 2006; Speck et al., 2008). However, in general, information on the nature of the streptococcal species and their host distribution is

The GenBank/EMBL/DDBJ accession numbers for the 16S rRNA, rpo $B$ and sod $A$ gene sequences of strain $2777-2-07^{\top}$ are FN813250, FN821809, FN821810, respectively.

A supplementary table and three supplementary figures are available with the online version of this paper. extremely poor and there are still many unknown or poorly understood aspects of the wildlife diseases. In this study, a septicaemic process affecting a Pyrenean chamois (Rupicapra pyrenaica) from the National Hunting Reserve of Freser-Setcases in the Pyrenees (NE Spain) was investigated. The animal was captured alive and transported to the facilities of the Wildlife Diseases Research Group at Universitat Autonoma of Barcelona. It arrived dying and was euthanized and necropsied. Macroscopically, multiple abscesses in the liver and subendocardic haemorrhages were observed. The main histological lesions were foci of suppurative necrosis in the spleen and liver. A coccusshaped organism was isolated in pure culture from spleen (1382-7-09), liver abscess (1382-6-09) and liver $\left(2777-2-07^{\mathrm{T}}\right)$ on Columbia blood agar plates (bioMérieux) incubated for $24 \mathrm{~h}$ at $37{ }^{\circ} \mathrm{C}$ under both aerobic and anaerobic [with $4-10 \% \mathrm{CO}_{2}$ using GasPak Plus (BBL) system] conditions. On the basis of the phenotypic and phylogenetic results, a novel species of the genus Streptococcus, Streptococcus rupicaprae sp. nov., is proposed.

A phylogenetic analysis was performed by comparative $16 \mathrm{~S}$ rRNA gene sequence analysis as described previously (Vela et al., 2002). A large, continuous fragment (approx. 1440 
bases) of the $16 \mathrm{~S}$ rRNA gene of one isolate $\left(2777-2-07^{\mathrm{T}}\right)$ and $1000 \mathrm{nt}$ from the other two isolates (1382-6-09 and 1382-7-09) was obtained bidirectionally using universal primers pA (5'-AGAGTTTGATCCTGGCTCAG-3'; positions 8-27, Escherichia coli numbering) and $\mathrm{pH}^{*}$ (5'-AAGGAGGTGATCCAGCCGCA-3'; positions 15411522, E. coli numbering). Comparative sequence analysis revealed $100 \%$ sequence similarity between the isolates, thereby demonstrating their high genealogical relatedness. Sequence searches of GenBank using the program FASTA (Pearson, 1994) revealed that the unknown cocci were member of the genus Streptococcus, being most closely related to Streptococcus ovis $\mathrm{S} 369 / 98 / 1^{\mathrm{T}}$ (95.9\% $16 \mathrm{~S}$ rRNA gene sequence similarity). Sequence similarity of isolate $2777-2-07^{\mathrm{T}}$ with other species of the genus Streptococcus was less than $95.3 \%$. This sequence and those of other representative species with validly published names within the genus Streptococcus were retrieved from GenBank and aligned with the newly determined sequence using the program SEQtools (Rasmussen, 2002). Phylogenetic trees were reconstructed according to three different algorithms: neighbour-joining (Saitou \& Nei, 1987) using the programs SEQtools and TreeView (Page, 1996; Rasmussen, 2002), maximum-parsimony using the software package MEGA version 4 (Kumar et al., 2004) and maximum-likelihood using the PHYML software (Guindon \& Gascuel, 2003). Genetic distances for the neighbour-joining algorithm were calculated by the Kimura two-parameter model (Kimura, 1980) and close-neighbour-interchange (search level=2, random additions $=100$ ) was applied in the maximumparsimony analysis. The stability of the groupings was estimated by bootstrap analysis (1000 replications). The maximum-likelihood tree was calculated using the GTR model (Lanave et al., 1984), based on the hillclimbing principle and estimated proportion of invariable sites, as well as the Gamma distribution parameter. The parameters in the program PHYML were as follows: input sequences are interleaved, with 500 non-parametric bootstrap analysis, GTR model of nucleotide substitution, 4 substitution rate categories, fixed Gamma distribution parameter $($ alpha $=2.00)$. Phylogenetic trees obtained by using the neighbour-joining (Fig. 1; an extended version of this tree is available as Supplementary Fig. S1 in IJSEM Online) and the other two methods (data not shown) revealed a clear affiliation of the unknown cocci (as exemplified by strain $2777-2-07^{\mathrm{T}}$ ) to the genus Streptococcus. It is evident from the phylogenetic tree based on the neighbourjoining algorithm (Fig. 1) that isolate $2777-2-07^{\mathrm{T}}$ formed a distinct subline, clustering within a small subgroup of species (embracing S. ovis, Streptococcus minor, Streptococcus merionis and Streptococcus gallinaceus). Although bootstrap resampling analysis did not demonstrate a significant association between isolate $2777-2-07^{\mathrm{T}}$ and the aforementioned species, the different branches were supported by the results of the other two algorithms. 16S rRNA sequence divergence values of $>4 \%$ between the novel isolate and $S$. ovis suggests that it represents a distinct species (Stackebrandt \& Goebel, 1994).

Sequence analysis of $\operatorname{sod} A$ and $r p o B$ genes has been demonstrated to be a useful tool for differentiating streptococci on phylogenetic grounds (Poyart et al., 1998, 2002; Drancourt et al., 2004). Partial sequences of $r p o B$

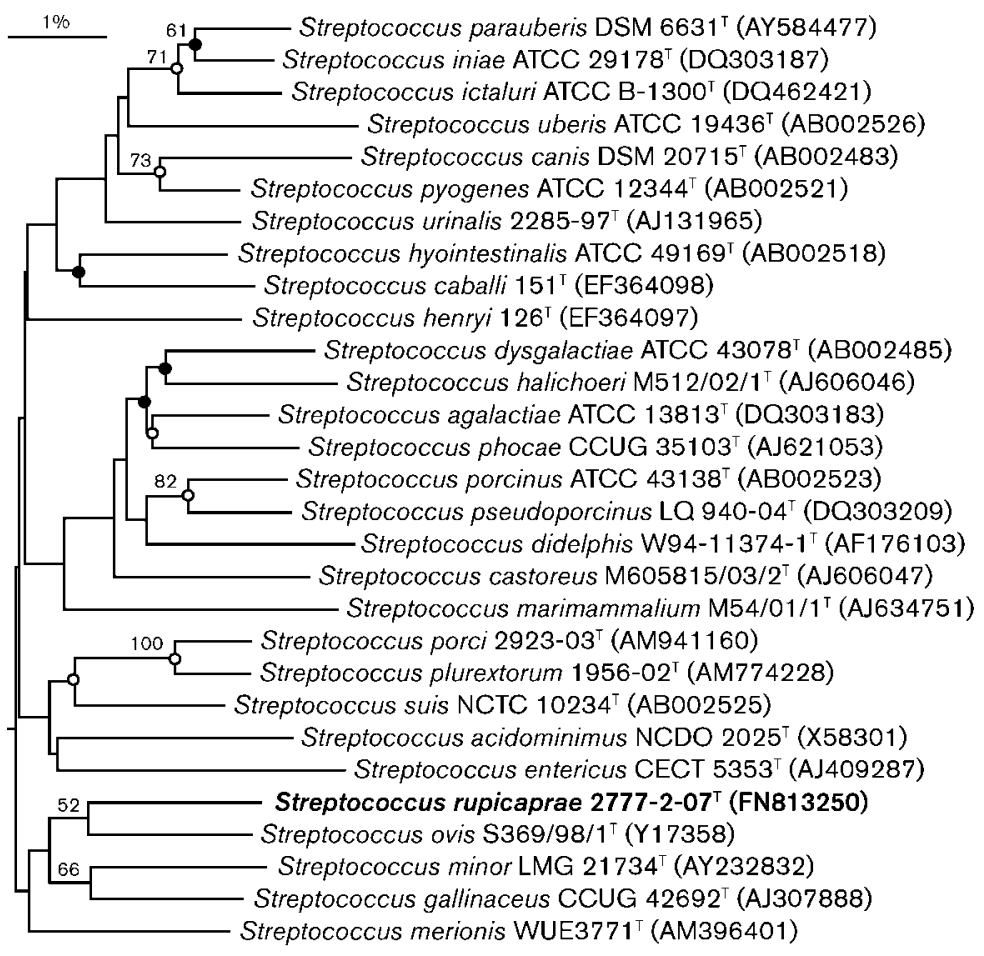

Fig. 1. Partial neighbour-joining phylogenetic tree inferred from comparison of 16S rRNA gene sequences showing the position of strain 2777-2-07 ${ }^{\top}$ (Streptococcus rupicaprae sp. nov.) and its closest phylogenetic neighbours. Enterococcus faecalis ATCC $19433^{\top}$ was used as the out-group. Filled circles indicate that the corresponding nodes (groupings) are also obtained in the parsimony tree. Open circles indicate that the corresponding nodes (groupings) are also obtained in the maximum-likelihood and parsimony trees. Bootstrap values (expressed as a percentage of 1000 replications) higher than $50 \%$ are given at the branching points. The different branches were supported by the results of the other two algorithms. Bar, $1 \%$ sequence divergence. 
(701 bp) and sodA (356 bp) genes were amplified using primer pair $\mathrm{d} 1$ and $\mathrm{d} 2$ (Poyart et al., 1998) and primers StreptoF and StreptoR (Drancourt et al., 2004), respectively, and sequenced as described previously (Glazunova et al., 2006). The three isolates shared $100 \%$ similarity for the $r p o B$ and sodA gene sequences, respectively. When comparing the $r p o B$ and $\operatorname{sod} A$ gene sequences of strain $2777-2-07^{\mathrm{T}}$ with those from the type strains of species of the genus Streptococcus available in GenBank, the highest sequence similarity for isolate $2777-2-07^{\mathrm{T}}$ was with $S$. ovis CIP $107097^{\mathrm{T}}(82.8 \%)$ based on the sodA gene, while it shared the highest sequence similarity with $S$. minor CIP $108314^{\mathrm{T}}$ and S. ovis CIP $107097^{\mathrm{T}}(85.7 \%$ and $85.6 \%$, respectively) based on the $r p o B$ gene. Evolutionary distances, the resulting trees and bootstrap values were determined as described above. Isolate $2777-2-07^{\mathrm{T}}$ formed a separate branch from other species of the genus Streptococcus in the phylogenetic trees inferred from $r p o B$ and sodA gene sequence comparisons (Supplementary Figs S2 and S3, respectively).

The determination of the $\mathrm{G}+\mathrm{C}$ content of the DNA of one representative isolate (strain $2777-2-07^{\mathrm{T}}$ ) was performed at the DSMZ (Braunschweig, Germany) by using the HPLC method of Mesbah et al. (1989). The DNA G + C content of the type strain was $43.8 \mathrm{~mol} \%$.

The three new isolates were Gram-stained and assessed for the presence of catalase. Haemolytic reaction was determined on Columbia agar containing $5 \%$ defibrinated sheep blood (bioMérieux) incubated aerobically at $37{ }^{\circ} \mathrm{C}$ for 24 and 48 h (Facklam \& Elliott, 1995). Determination of growth at $15,22,30,37$ and $42{ }^{\circ} \mathrm{C}$ was performed in brain heart infusion broth (Difco) with the $\mathrm{pH}$ adjusted to 7.5 (Facklam \& Elliott, 1995). The ability of the isolates to tolerate the presence of 3, 4.5 and $6.5 \% \mathrm{NaCl}$ was assessed as recommended by Facklam \& Elliott (1995). Growth at pH 9.6 was assessed in brain heart infusion broth (Facklam \& Elliott, 1995). Lancefield serological group reaction was determined with the commercial Slidex Strepto kit (bioMérieux) by using specific group $\mathrm{A}, \mathrm{B}, \mathrm{C}, \mathrm{D}, \mathrm{F}$ and $\mathrm{G}$ streptococcal latex agglutinating antisera. The isolates were biochemically characterized using the Rapid ID32 Strep, API $50 \mathrm{CH}$ and API ZYM systems (bioMérieux) according to the manufacturer's instructions. The API 50 $\mathrm{CH}$ strips using the $\mathrm{CHB}$ suspension medium were read at up to 7 days of incubation at $37^{\circ} \mathrm{C}$. Isolates exhibited almost identical biochemical characteristics, except for the production of glycyl-tryptophan arylamidase (isolate 13826-09 was positive).

Strain $2777-2-07^{\mathrm{T}}$ is phylogenetically related to streptococcal species, such as S. ovis, S. minor and S. gallinaceus, not assigned to any of the major recognized species groups (Wheiley \& Hardie, 2009). Phenotypic characteristics that differentiate the proposed species from closely related species are shown in Table 1. Determination of the Lancefield group antigen is still an important routine identification technique (Quinn et al., 1999). S. rupicaprae sp. nov. reacted with Lancefield group D antisera and, in addition to the closely related species $S$. gallinaceus (see Table 1), it can be differentiated from other streptococci of the Lancefield group D by several biochemical characteristics (Supplementary Table S1).

Overall, the results of the present study show that the unidentified catalase-negative cocci merit classification as a novel species of the genus Streptococcus, for which the name Streptococcus rupicaprae sp. nov. is proposed. Although it was isolated from the liver and spleen of a chamois with a septicaemic process, it is not possible to draw conclusions about the clinical significance of the novel species.

\section{Description of Streptococcus rupicaprae sp. nov.}

Streptococcus rupicaprae (ru.pi.cap'rae. L. fem. n. rupicapra chamois; L. fem. gen. n. rupicaprae of a chamois).

Cells are Gram-stain-positive, non-spore-forming cocci, $0.7-1 \mu \mathrm{m}$ in diameter, occurring in pairs or chains commonly over 7-10 cells long. Colonies on blood agar are small, circular and non-pigmented, $0.75-1.0 \mathrm{~mm}$ in diameter and $\alpha$-haemolytic at $37^{\circ} \mathrm{C}$. Cells are facultatively anaerobic, catalase-negative and non-motile. Reacts with Lancefield group D antisera. Cells are able to grow at 22, 30, 37 and $42{ }^{\circ} \mathrm{C}$ but do not grow at $15{ }^{\circ} \mathrm{C}$. Growth occurs at $\mathrm{pH} 9.6$ and in the presence of $3 \% \mathrm{NaCl}$ but not in broth containing 4.5 or $6.5 \% \mathrm{NaCl}$. With the API $50 \mathrm{CH}$ and Rapid ID32 Strep kits, cells are able to produce acid from D-xylose, D-galactose, D-glucose, D-fructose, D-mannose, L-rhamnose, $\mathrm{N}$-acetylglucosamine, amygdalin, arbutin, aesculin, salicin, cellobiose, maltose, lactose, sucrose, trehalose, inulin, raffinose, starch, glycogen, melibiose, pullulan, L-arabinose, gentiobiose and methyl $\beta$-D-glucopyranoside but not from glycerol, erythritol, D-arabinose, D-ribose, L-xylose, D-adonitol, methyl $\beta$-D-xylopyranoside, L-sorbose, L-arabitol, D-arabitol, D-mannitol, D-sorbitol, inositol, dulcitol, methyl $\alpha$-D-mannopyranoside, methyl $\alpha$-Dglucopyranoside, melezitose, turanose, D-lyxose, xylitol, D-fucose, L-fucose, 2-ketogluconate, 5-ketogluconate, cyclodextrin or tagatose. Leucine arylamidase, $\beta$-galactosidase (API ZYM), $\beta$-glucuronidase (API ZYM and Rapid ID32 Strep), $\beta$-mannosidase and alanine-phenylalanine-proline arylamidase (Rapid ID32 Strep) are detected. No activity is detected for acid phosphatase, naphthol-AS-BIphosphohydrolase, $\alpha$-mannosidase, $\alpha$-fucosidase, esterase C4, ester lipase C8, lipase C14, valine arylamidase, $\alpha$ glucosidase, cystine arylamidase, trypsin, $\alpha$-chymotrypsin (API ZYM), $N$-acetyl- $\beta$-glucosaminidase, alkaline phosphatase (API ZYM and Rapid ID32 Strep) or pyroglutamic acid arylamidase (Rapid ID32 Strep). Cells produce $\beta$-glucosidase and $\alpha$-galactosidase using the Rapid ID32 Strep system. Arginine is hydrolysed but not hippurate or urea (Rapid ID32 Strep). Type strain $\left(2777-2-07^{\mathrm{T}}\right)$ does not produce glycyl-tryptophan arylamidase (Rapid ID 32 Strep). Acetoin is not produced (Rapid ID 32 Strep).

The type strain, $2777-2-07^{\mathrm{T}}\left(=\mathrm{CECT} 7718^{\mathrm{T}}=\right.$ CCUG $59652^{\mathrm{T}}$ ), was isolated from the liver of a chamois with 
Table 1. Characteristics useful in differentiating strain $2777-2-07^{\top}$ from closely related species of the genus Streptococcus

Strains: 1, S. rupicaprae sp. nov. 2777-2-07 ${ }^{\mathrm{T}}$; 2, S. ovis CCUG $39485^{\mathrm{T}}$; 3, S. minor CCUG $47487^{\mathrm{T}}$; 4, S. merionis CCUG 54871 ${ }^{\mathrm{T}}$; 5, S. gallinaceus CCUG $42692^{\mathrm{T}} ; 6$, Streptococcus pyogenes CCUG $4207^{\mathrm{T}}$. S. pyogenes was included as representative type species of the genus Streptococcus. Lancefield serological group reaction using group A-, B-, C-, D-, F- and G-specific streptococcal latex agglutinating antisera. Phenotypic data for all strains from this study. +, Positive reaction; -, negative reaction; NG, non-groupable; PA, polyagglutination reaction with A, B, C, D, F and G antisera; ${ }^{\mathrm{W}}$, weak reaction.

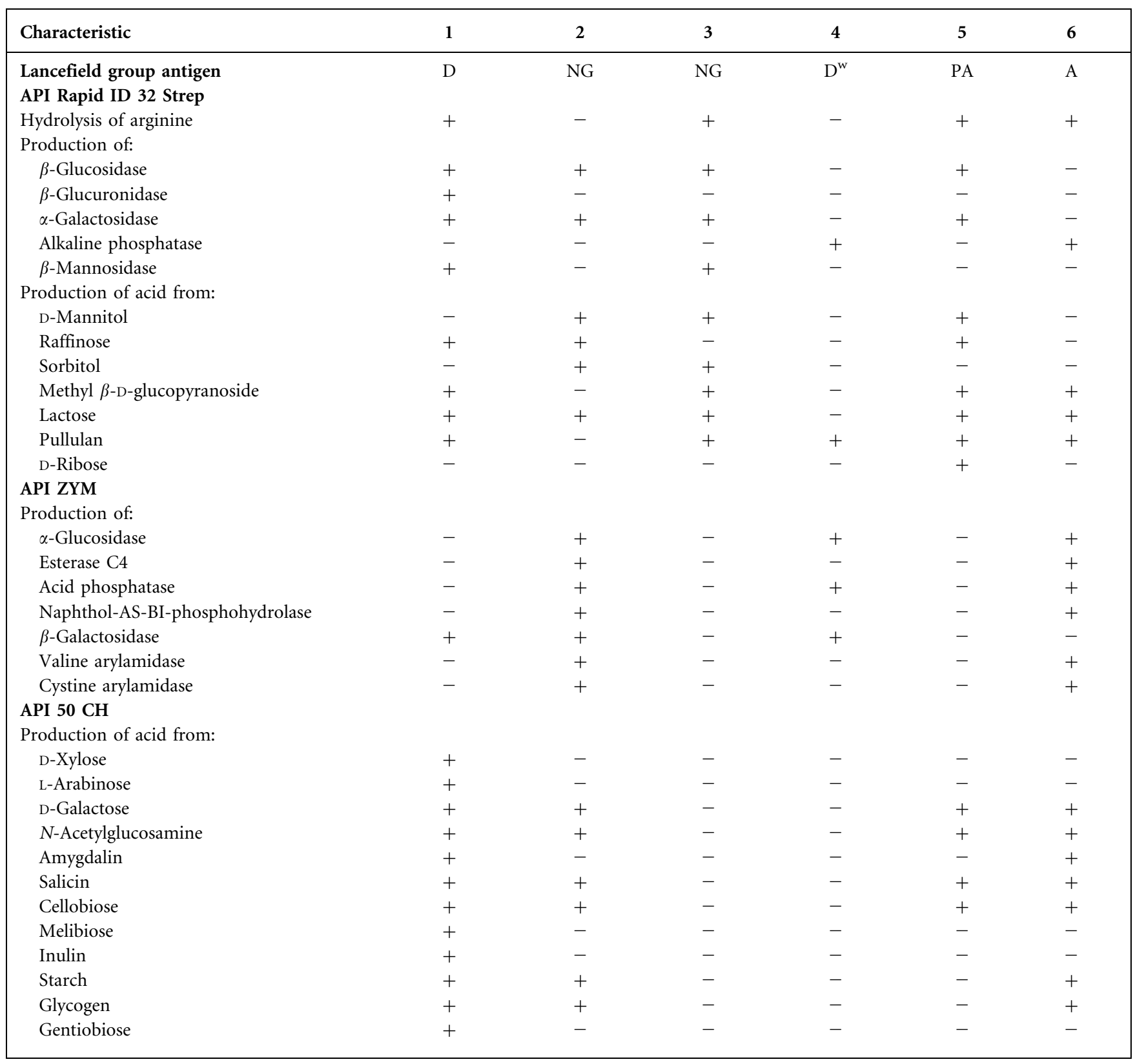

septicaemia. Full range of habitat is not known. The DNA $\mathrm{G}+\mathrm{C}$ content is $43.8 \mathrm{~mol} \%$.

\section{Acknowledgements}

This work was funded by the Spanish Ministry of Education and Science (MEC), project AGL2009-14303-C02-01. The authors thank N. Carmona for technical assistance and Juncal Fernández-Garayzábal for her assistance with the English reviewing of the manuscript.

\section{References}

Chanter, N. (1997). Streptococci and enterococci as animal pathogens. Soc Appl Bacteriol Symp Ser 26 (Suppl), 100S-109S.

Drancourt, M., Roux, V., Fournier, P. E. \& Raoult, D. (2004). rpoB gene sequence-based identification of aerobic Gram-positive cocci of the genera Streptococcus, Enterococcus, Gemella, Abiotrophia, and Granulicatella. J Clin Microbiol 42, 497-504.

Facklam, R. R. \& Elliott, J. A. (1995). Identification, classification, and clinical relevance of catalase-negative, gram-positive cocci, 
excluding the streptococci and enterococci. Clin Microbiol Rev 8, 479-495.

Glazunova, O. O., Raoult, D. \& Roux, V. (2006). Streptococcus massiliensis sp. nov., isolated from a patient blood culture. Int J Syst Bacteriol 56, 1127-1131.

Guindon, S. \& Gascuel, O. (2003). A simple, fast, and accurate algorithm to estimate large phylogenies by maximum likelihood. Syst Biol 52, 696-704.

Höner, O. P., Wachter, B., Speck, S., Wibbelt, G., Ludwig, A., Fyumagwa, R. D., Wohlsein, P., Lieckfeldt, D., Hofer, H. \& East, M. L. (2006). Severe Streptococcus infection in spotted hyenas in the Ngorongoro Crater, Tanzania. Vet Microbiol 115, 223-228.

Kilian, M. (1998). Streptococcus and Lactococcus. In Topley \& Wilson's Microbiology and Microbial Infections, vol. 2, Systematic Bacteriology, pp. 633-667. Edited by A. Balows \& B. I. Duerden. London: Arnold.

Kimura, M. (1980). A simple method for estimating evolutionary rates of base substitutions through comparative studies of nucleotide sequences. J Mol Evol 16, 111-120.

Kumar, S., Tamura, K. \& Nei, M. (2004). MEGA3: integrated software for molecular evolutionary genetics analysis and sequence alignment. Brief Bioinform 5, 150-163.

Lanave, C., Preparata, G., Saccone, C. \& Serio, G. (1984). A new method for calculating evolutionary substitution rates. J Mol Evol 20, 86-93.

Mesbah, M., Premachandran, U. \& Whitman, W. B. (1989). Precise measurement of the GC content of deoxyribonucleic acid by highperformance liquid chromatography. Int J Syst Bacteriol 39, 159-167.

Page, R. D. M. (1996). TreeView: an application to display phylogenetic trees on personal computers. Comput Appl Biosci 12, 357-358.

Pearson, W. R. (1994). Using the FASTA program to search protein and DNA sequence databases. Methods Mol Biol 24, 307-331.

Poyart, C., Quesne, G., Coulon, S., Berche, P. \& Trieu-Cuot, P. (1998). Identification of streptococci to species level by sequencing the gene encoding the manganese-dependent superoxide dismutase. $J$ Clin Microbiol 36, 41-47.

Poyart, C., Quesne, G. \& Trieu-Cuot, P. (2002). Taxonomic dissection of the Streptococcus bovis group by analysis of manganese-dependent superoxide dismutase gene $(\operatorname{sod} A)$ sequences: reclassification of 'Streptococcus infantarius subsp. coli' as Streptococcus lutetiensis sp. nov. and of Streptococcus bovis biotype 11.2 as Streptococcus pasteurianus sp. nov. Int J Syst Evol Microbiol 52, 1247-1255.

Quinn, P. J., Carter, M. E., Markey, B. \& Carter, G. R. (1999). The streptococci and related cocci. In Clinical Veterinary Microbiology, pp. 127-136. Edited by P. J. Quinn, M. E. Carter, B. Markey \& G. R. Carter. Edinburgh: Mosby.

Rasmussen, S. W. (2002). SEQtools, a program suite for sequence analysis. Copenhagen: Carlsberg Laboratory.

Rurangirwa, F. R., Teitzel, C. A., Cui, J., French, D. M., McDonough, P. L. \& Besser, T. (2000). Streptococcus didelphis sp. nov., a streptococcus with marked catalase activity isolated from opossums (Didelphis virginiana) with suppurative dermatitis and liver fibrosis. Int J Syst Evol Microbiol 50, 759-765.

Saitou, N. \& Nei, M. (1987). The neighbor-joining method: a new method for reconstructing phylogenetic trees. Mol Biol Evol 4, $406-425$.

Speck, S., Höner, O. P., Wachter, B. \& Fickel, J. (2008). Characterization of Streptococcus equi subsp. ruminatorum isolated from spotted hyenas (Crocuta crocuta) and plains zebras (Equus burchelli), and identification of a M-like protein (SrM) encoding gene. Vet Microbiol 128, 148-159.

Stackebrandt, E. \& Goebel, B. M. (1994). Taxonomic note: a place for DNA-DNA reassociation and $16 \mathrm{~S}$ rRNA sequence analysis in the present species definition in bacteriology. Int J Syst Bacteriol 44, 846-849.

Szentiks, C. A., Köndgen, S., Silinski, S., Speck, S. \& Leendertz, F. H. (2009). Lethal pneumonia in a captive juvenile chimpanzee (Pan troglodytes) due to human-transmitted human respiratory syncytial virus (HRSV) and infection with Streptococcus pneumoniae. J Med Primatol 38, 236-240.

Vela, A. I., Fernández, E., Lawson, P. A., Latre, M. V., Falsen, E., Domínguez, L., Collins, M. D. \& Fernández-Garayzábal, J. F. (2002). Streptococcus entericus sp. nov., isolated from cattle intestine. Int J Syst Evol Microbiol 52, 665-669.

Wheiley, R. A. \& Hardie, J. M. (2009). Genus I. Streptococcus Rosenbach 1884, 22 $2^{\mathrm{AL}}$. In Bergey's Manual of Systematic Bacteriology, 2nd edn, vol. 3, pp. 655-711. Edited by P. de Vos, G. Garrity, D. Jones, N. R. Krieg, W. Ludwig, F. A. Rainey, K. H. Schleifer \& W. B. Whitman. New York: Springer. 